\title{
An Empirical Study of College English Autonomous Learning Ability Based on Flipping Classroom Mode
}

\author{
Qiu Weiqiang \\ School of Foreign Language \\ Fujian Jiangxia University \\ Fuzhou, Fujian 350108, China
}

\begin{abstract}
Cultivating students' autonomous learning ability is one of the important goals of college English education. Based on the theory of constructivism and relying on the network platform, this study constructed a flipping classroom teaching model. By means of comparative teaching, questionnaires, interviews and other research methods, this study investigated the current situation of the autonomous learning ability of non-English majors. The effect of flipping classroom teaching model on college English autonomous learning ability was analyzed statistically. The results showed that flipping classroom autonomous learning model could effectively improve students' autonomous learning ability and English proficiency.
\end{abstract}

Keywords-College English; Flipping classroom model; Autonomous learning; Empirical study

\section{RESEARCH BACKGROUND}

Since 1980's, autonomous learning has become an important topic in the field of second language acquisition. In English teaching, "cultivating students' autonomous learning ability is an important goal of education" [1], and the cultivation of autonomous learning ability is a process from a training of self-management learning ability, the change of learning psychology to the formation of autonomous learning behavior. A large number of domestic scholars' studies showed that: at present, the ability of autonomous learning of college students in China is generally weak, [2] which is mainly due to the serious influence of traditional teaching ideas and exam-oriented teaching. The main character of the teaching is the teacher, students lack the consciousness of autonomous learning, and there is no interactive and cooperative teaching atmosphere between teachers and students. Therefore, the reform of teaching mode is the key to cultivate the autonomous learning ability of college students. An important sign of the success of the new teaching model is the formation of students' individualized learning methods and the development of students' autonomous learning ability [3]. In view of this situation, based on the network curriculum platform, the Internet and other teaching resources, this paper constructs a flipping classroom teaching model, and examines the impact of flipping classroom teaching on the development of college English autonomous learning ability through

Fund project: 2017 Educational research project for young and middle-aged teachers of Fujian Province (Special project for college foreign language teaching reform) "Construction of college English autonomous learning model based on flipped classroom"(JZ 170086); Horizontal fund project of Fujian Jiangxia University( JXH2017022) empirical research.

\section{REVIEW OF RELEVANT LITERATURE}

\section{A. Flipping Classroom}

Jonathan Berman and Aaron Summs, two chemistry teachers at Woodland Park High School in Rocky Mountain, Colorado, have boldly carried out the practice of flipping classroom teaching in the classroom, which successfully opened the first step of flipping classroom teaching in 2012. Jeremy F. Streyer studied cooperation in the flipping class, arguing that flipping class gave students the initiative to learn, and that students were able to learn at their own pace according to their cognitive styles and habits, and it's beneficial to cultivate students' autonomous learning ability. [4]Since then, the flipping classroom has gradually aroused the concern of the global educational circles. The research mainly focuses on: the application of flipping classroom in teaching practice, the comparison with the traditional teaching mode, the effect of combining with other teaching methods, the implementation steps, the video development.

As a new teaching model, the biggest difference between flipped classroom and traditional teaching lies in: first, the flipping classroom pays attention to the cultivation of students' self-study ability, and improves students' ability to collect information, analyze and use information synthetically. Secondly, the subject of the flipping classroom has changed, the teacher has returned the initiative in the classroom to the students, and the students' self-management ability of learning has been strengthened and become the real subject of learning. In addition, the flipped classroom provides more face-to-face communication and learning opportunities between students, and between teachers and students, and the teaching content is more targeted. Flipping classroom is not only the embodiment of "student subject" teaching idea, but also is the process which teachers pay constant attention to students' study with the help of modern information technology, and it better realizes students' individualized learning and teachers' individualized guidance.

\section{B. Autonomous Learning}

Many scholars at home and abroad have made relevant research on autonomous learning. Reinders put forward the conceptual framework of autonomous learning. The elements 
of the framework include: clear requirements, goals setting, making plans, selection of resources, using strategies, practice, self-monitoring, self-evaluation.[5]Reinders and White pointed out that autonomous learning has the characteristics of independence and interdependence. Learners should pay attention to their own learning behavior and cultivate their sense of responsibility to promote their autonomy in language learning.[6] Murray believed that autonomous learning includes a social dimension, and becoming an autonomous learner is mainly a social process.[7]Sui Xiaobing studied the anxiety of English learners under multimedia network, and found that anxiety factors would hinder students' autonomous learning.[8] Du Zhongquan found free space for students' autonomous learning is limited, college English teachers still interfere too much with students' learning activities, which leads to students' lack of enthusiasm for autonomous learning.[9]With the deepening and expanding of foreign language autonomous learning theory, the research has made great achievements from theory to practice, involving the autonomous learning model, the social and cultural connotation of autonomous learning, and the autonomy of teachers. And language autonomous learning centers under computer-assisted instruction have also developed rapidly. The domestic and foreign scholars' research on autonomous learning has made a lot of achievements, which has injected new vitality into the teaching reform.

\section{The Necessity of this Study}

The effectiveness of the flipped classroom largely depends on students' autonomous learning. Autonomous learning ability is not only the guarantee of the smooth implementation of flipping classroom, but also the key to test whether the flipping classroom teaching model is effective. Therefore, the study of the effect of flipping teaching on English autonomous learning ability can not only test whether the teaching mode is suitable for English course teaching, but also understand the present situation of students' autonomous learning ability. Based on the empirical research, this study explores the effect of flipping teaching on English autonomous learning ability, which has theoretical and practical significance.

\section{RESEARCH DESIGN}

\section{A. Contents and Participants of Study}

This study takes the freshmen of non-English major in a university as the research object. The experimental class carries out flipping classroom teaching, while the control class continues the traditional teaching. Based on the size of the sample, both the experimental class and the traditional class choose two science classes.

This study focuses on the effect of flipping classroom teaching on the development of students' English autonomous learning ability. On the basis of studying the present situation of the freshmen's autonomous learning ability, the contrastive teaching of flipping teaching and traditional teaching is carried out, and the overall satisfaction and acceptance of flipping teaching are studied through questionnaires and interviews. Specifically, the study focuses on three questions: (1) How about the autonomous learning ability of the freshmen? (2)Whether the flipping teaching can improve the English autonomous learning ability and the English achievement? (3) What are the students' participation in the flipping teaching and their overall evaluation?

\section{B. Research Methods and Tools}

This study adopts case study method to combine quantitative research with qualitative research and collects relevant data through questionnaire, English test; structured interview . This study uses the course platform to carry on the on-line teaching, which meets the needs of flipping teaching.

\section{Data Reliability}

The reliability test of the questionnaire shows that: the internal unity of the five dimensions (32 factor variables) of the questionnaire of Autonomous Learning ability scale has reached the statistical requirement, and the reliability coefficient of the whole volume (Cronbach's Alpha) is 0.848, which exceeds the theoretical requirement of 0.70 , and indicates that the reliability of the questionnaire is very good.

\section{The Concrete ImPlementation SteP OF FLIPPING TEACHING}

\section{A. Autonomic Learning before Class}

The teacher divides the teaching content into several small tasks, each of which covers new knowledge points. The teacher made about 8 minutes of microvideo in advance, shares the microvideo resource with the learners with the help of online platform, and attaches the task list of autonomous learning that the students need to complete, let the students understand the difficulties and key points of the unit while completing the task list, so as to check whether the students have mastered the knowledge points. At the same time, in order to communicate with the students in time, students are asked to release the problems and puzzles in their study to the platform, so as to facilitate the exchange and share between teachers and students.

\section{B. Transmission of Knowledge in Class}

According to the content feedback of students' autonomous learning stage before class, the teacher determines the teaching goal and gives students the opportunity to show their autonomous learning results. Students actively participate in classroom activities, report on the results of autonomous learning before class, including the problems they can not solve. Presentations can be as varied as possible, including presentations, role-playing, games, debates, etc. According to the report of students' autonomous learning, teachers point out their shortcomings, and put forward solutions to help students sort out and explore and stimulate students' interest in learning. In class students should increase oral output, improve the comprehensive use of English. For the problems that students fail to solve before class, can be solved through group discussions and joint exploration. According to the students' learning attitude, learning ability and learning style, teachers can make a comprehensive evaluation and summary, point out the problems in the students' learning of new knowledge, and promote the internalization of students' knowledge. 


\section{Autonomous Learning after Class}

Students can learn independently in various resource platforms and master the main points of knowledge through watching micro-video, according to their current English level, with the help of a variety of mobile terminal equipment, learning time, content and location can be self-control. Teachers can guide students to consciously explore and think about the problems encountered in the process of learning, so that their analytical and problem-solving ability can be cultivated. Meanwhile, teachers provide timely guidance to puzzles encountered by students through various ways of online communication with students, in order to promote their autonomous learning after class.

\section{RESUlts AND ANALysis}

\section{A. Present Situation of Autonomous Learning Ability}

The pre-test data of autonomous learning ability (see TABLE I) shows that the mean value of each dimension of students' autonomous learning ability in experimental class and traditional class is lower than 3. 0 (Likert 5 component table).Therefore, we can conclude that the overall autonomous learning ability of students is on the low side. Independent sample T test (see TABLE I) shows that there is no significant difference in autonomous learning ability between the experimental class and the traditional class at the beginning of experiment.

\section{B. The Effect of Flipping Classroom Teaching on English Autonomous Learning Ability and Achievement}

The overall influence of flipping teaching on English autonomous Learning ability

As shown in TABLE I, flipping teaching can significantly improve English autonomous learning ability. The independent sample $\mathrm{T}$ test before the autonomous learning ability test shows that the $\mathrm{P}$ value is equal to 0.691 , which is far more than 0.05 , so there is no significant difference in the five dimensions of autonomous learning ability between the experimental class and the traditional class. After nearly a semester of comparative teaching, the descriptive statistical analysis of autonomous learning ability shows that the mean value of each dimension of the experimental class is higher than that of the traditional class. The post-test independent sample T test shows that $\mathrm{P}$ value is 0.039 , less than 0.05 , so the level of the five dimensions of autonomous learning ability in the experimental class is significantly higher than that in the traditional class. In addition, the improvement value of autonomous learning ability in the experimental class is significantly higher than that in the traditional class. The independent sample $\mathrm{T}$ test also shows that $\mathrm{P}$ value is equal to 0.001 , and the difference of progressive value between the two classes is very significant.

TABLE I. DATA OF THE AUTONOMOUS LEARNING ABILITY OF EXPERIMENTAL CLASS AND TRADITIONAL CLASS

\begin{tabular}{|c|c|c|c|c|c|c|}
\hline \multirow{3}{*}{ Dimension } & \multicolumn{2}{|c|}{ Pre-Test } & \multicolumn{2}{|c|}{ Post-Test } & \multicolumn{2}{|c|}{ Improvement Value } \\
\hline & Experimental Class & $\begin{array}{l}\text { Traditional } \\
\text { Class }\end{array}$ & Experimental Class & $\begin{array}{l}\text { Traditional } \\
\text { Class }\end{array}$ & \multirow[t]{2}{*}{ Experimental Class } & \multirow[t]{2}{*}{ Traditional Class } \\
\hline & Mean & Mean & Mean & Mean & & \\
\hline $\begin{array}{l}\text { Understanding } \\
\text { Teaching Goal }\end{array}$ & 2.82 & 2.83 & 3.19 & 2.95 & 0.43 & 0.16 \\
\hline $\begin{array}{l}\text { Making Learning } \\
\text { Goals \&Plans }\end{array}$ & 2.51 & 2.43 & 2.86 & 2.53 & 0.36 & 0.08 \\
\hline $\begin{array}{l}\text { Effective Use } \\
\text { Of Learning } \\
\text { Strategy }\end{array}$ & 2.41 & 2.28 & 2.83 & 2.45 & 0.41 & 0.17 \\
\hline $\begin{array}{c}\text { Monitoring } \\
\text { Learning Strategy }\end{array}$ & 2.62 & 2.56 & 2.98 & 2.85 & 0.39 & 0.31 \\
\hline $\begin{array}{c}\text { Monitor And } \\
\text { Evaluate Learning } \\
\text { Process }\end{array}$ & 2.47 & 2.51 & 2.92 & 2.52 & 0.43 & 0.00 \\
\hline $\begin{array}{c}\text { T-Test Sig. Value } \\
\text { (P Value) }\end{array}$ & \multicolumn{2}{|c|}{0.691} & \multicolumn{2}{|c|}{0.039} & \multicolumn{2}{|c|}{0.001} \\
\hline Deviation & \multicolumn{2}{|c|}{$\mathrm{P}>0.05$} & \multicolumn{2}{|c|}{$\mathrm{P}<0.05$} & \multicolumn{2}{|c|}{$P \leqslant 0.001$} \\
\hline
\end{tabular}

\section{The Effect of Flipping Teaching on Academic Achievement}

A large number of studies have shown that autonomous learning ability is closely related to academic achievement. In order to further test the effect of flipping teaching on autonomous learning ability, this study carries out differential test of the entrance scores and the final English test scores at the end of the term between the experimental class and the traditional class. Pre-test independent sample T test shows no significant difference between the two classes. After the contrastive teaching, the post-test independent sample $\mathrm{T}$ test shows that the average score of the experimental class is 5.13 higher than that of the traditional class, and the $\mathrm{P}$ value was 0.000 , which indicates that the final grade of the experimental class is significantly higher than that of the traditional class. In addition, the standard deviation of the experimental class (8.01) is obviously lower than that of traditional class (11.63), which also shows that flipping teaching is more beneficial to the overall improvement of students' academic achievement. 
TABLE II. FINAL TEST RESULTS OF EXPERIMENTAL CLASS AND TRADITIONAL CLASS

\begin{tabular}{|c|c|c|c|c|c|}
\hline Class & Average score & SD & Mean & $\begin{array}{c}\text { Test Sig. } \\
\text { Value(P Value) }\end{array}$ & Difference explanation \\
\hline Experimental class & 70.52 & 8.01 & \multirow{2}{*}{5.13} & 0.000 & $\begin{array}{c}\text { P } \leqq 0.001 \text { There's a } \\
\text { very significant } \\
\text { difference. }\end{array}$ \\
\cline { 1 - 3 } Traditional class & 65.39 & 11.63 & & & \\
\hline
\end{tabular}

\section{Students' Participation in Flipping Teaching and its Overall Evaluation}

The author conducts a questionnaire in the experimental class from five dimensions, including evaluation of the whole teaching effect of flipping teaching reform, the willingness to participate in flipping class, situation of autonomous learning before class, feedback of classroom activities, and the contrast of flipping teaching with traditional teaching.

The results show that students' overall satisfaction, participation and acceptance are higher. The overall satisfaction of students to the flipping teaching course is 85.69\%.78.53\% of students think that autonomous learning before class can make them better participate in classroom learning. $75.82 \%$ of students think that cooperation with others in class is very helpful to their study. $89.36 \%$ of the students think that flipping teaching is more beneficial to the improvement of autonomous learning ability. $82 \%$ of the students think that the new teaching model can improve the ability of solving and analyzing problems.. $86.23 \%$ of the students support continuing flipping teaching in future English teaching.

\section{CONCLUSION}

Based on the above data and analysis, the following referential conclusions can be drawn: flipping teaching can not only effectively promote the development of English autonomous learning ability, improve English learning achievement, but also help to develop students' ability of cooperation and innovation. Students' desire for knowledge and innovation are greatly stimulated under the flipping classroom model, and learners are more confident and the pressure of learning can be alleviated. Through interviews, the students say that the new teaching model makes them more confident in English learning. Through communication and cooperation with other students, they find that learning English is also a happy thing. Flipping teaching helps students to set up the consciousness of autonomous learning and stimulates students' learning motivation, is helpful for students to construct their own autonomous learning ability system from five dimensions of autonomous learning ability.

\section{REFERENCES}

[1] Pang Weiguo. On students' Autonomous Learning [J]. Journal of East China normal University (Educational Science Edition).2001(6):78-83.

[2] Xu Jinfen. An empirical study on the effect of extracurricular Cooperative Learning on College students' English Autonomous Learning ability[J]. Journal of the PLA Foreign language Institute .2013(5): 39-43.

[3] Xu Jinfen, $\mathrm{Xu}$ Li. On the Role of College English Teachers in Autonomous Learning [J]. Higher education research. 2004(3): 77-79.

[4] Jeremy F. Strayer. How Learning in an Inverted classroom influences cooperation, innovation and task orientation[J]. Learning Environments Research, 2012(15): 171-193.

[5] Reinders, H. Towards a classroom pedagogy for learner autonomy: A framework of independent language learning skills [J]. Australian Journal of Teacher Education, 2010, (5): 41-46.

[6] Reinders,H\& C. White. Special issue commentary: Learner autonomy and new learning environments[J].Language Learning \& Technology,2011( 3):1-3.

[7] Murray,G. The social dimensions of learner autonomy and self-regulated learning [J]. Studies in Self-Access Learning Journal.2014( 4):326-329.

[8] Sui Xiaobing. Study on anxiety of English Learners in Web-based Teaching Environment[J].Audio-Visual Foreign language Teaching.2012 (1):78-80.

[9] Du Zhongquan, Yun Tianying, Wang Xiaolai. On College English Autonomous Learning in the Network Environment [J] .Teaching practice and Research. 2012 (6):112-114. 